\title{
Malpighia emaginata D.C. Growth in Several Substrates and Salt Waters
}

\author{
Jackson Silva Nóbrega ${ }^{1}$, Ivando Comandante Macedo Silva ${ }^{2}$, Israel Almeida da Silva ${ }^{3}$, Reginaldo Gomes Nobre ${ }^{3}$, \\ Francisco Romário Andrade Figueiredo ${ }^{1}$, Francisco Marto de Souza ${ }^{1}$, Reynaldo Teodoro de Fátima ${ }^{1}$, \\ Jean Telvio Andrade Ferreira ${ }^{1} \&$ Rodrigo Garcia Silva Nascimento ${ }^{1}$ \\ ${ }^{1}$ Department Plant Science and Environmental Sciences, Federal University of Paraíba, Areia, Paraíba, Brazil \\ ${ }^{2}$ CIDAGRO, Mossoró, Brazil \\ ${ }^{3}$ Center of Science and Agri-food Technology, Federal University of Campina Grande, Pombal, Brazil \\ Correspondence: Jackson Silva Nóbrega, Department Plant Science and Environmental Sciences, Federal \\ University of Paraíba, Areia, Paraíba, Brazil. E-mail: jacksonnobrega@hotmail.com
}

Received: April 30, 2018

doi:10.5539/jas.v10n8p352
Accepted: June 1, $2018 \quad$ Online Published: July 15, 2018

URL: https://doi.org/10.5539/jas.v10n8p352

\begin{abstract}
The acerola tree is one of the most promising fruit trees of the Brazilian fruit sector, demanding the development of studies that indicate the proper conditions to improve its production under adverse conditions. Consequently, our purpose was to evaluate the growth of Malpighia emaginata D.C in several substrates and under ascending levels of irrigation water salinity. The experiment was conducted in a $4 \times 5$ factorial scheme randomized block design, which comprised four substrates ( $\mathrm{S} 1=$ soil; $\mathrm{S} 2=$ soil with a $10 \%$ addition of cattle manure; $\mathrm{S} 3=$ soil with a $10 \%$ addition of organic compounds; and $\mathrm{S} 4$ - soil with a $5 \%$ addition of cattle manure and a $5 \%$ addition of organic compounds) and five CEa salt levels $\left(0.3,1.0,1.7,2.7\right.$, and $\left.3.5 \mathrm{dS} \mathrm{m} \mathrm{m}^{-1}\right)$. The plant height and stem diameter variables were not affected by the studied factors. The interaction between salinity and the substrates affected the root growth and the build-up of the plants' fresh and dry biomass, resulting in the increase of the values obtained by the substrates containing manure and organic compounds. The seedlings' quality, represented by the height/stem diameter and aerial part/root dry mass ratios, and by the Dickson quality index, indicated that the plants produced in the substrates 2 and 3 were more vigorous.
\end{abstract}

Keywords: organic fertilization, salt stress, seedling production

\section{Introduction}

The acerola tree (Malpighia emaginata D.C.) is a fruit tree of high acceptance in the Brazilian fruit sector due to its favorable developing environmental features. Additionally, it presents pleasant features of taste and nutritional quality, with high levels of ascorbic acid, vitamin A and B complex, iron and calcium (Esashika, Oliveira, \& Moreira, 2013; Bezerra, Leite, Silva, Oliveira, \& Mello, 2017).

Obtaining good quality seedlings depends on several factors, including which substrate is used in their production. The choice of the substrate's elements is a fundamental factor to obtain good quality seedlings, and it is essential that such substrate provides a greater root system development and nutrient absorption (F. D. A. Oliveira, J. M. Oliveira, Souza Neta, M. K. T. Oliveira, \& Cássia Alves, 2017a). The use of organic residues in the substrate's composition, such as manure, organic compounds, worm castings, etc., improve their physical, chemical, and biological features and are promising alternatives for seedling production (Prates et al., 2012).

The hydric support and the quality of the water used in seedling productions is another feature that directly affects the plants' quality. An excessive high level of salt directly affects the growth of cultures, resulting in harmful effects in every phenological stage, especially during seedling formation (Medeiros et al., 2016). Additionally, it causes osmotic, toxic effects and the nutritional unbalance of the plants, resulting in morphophysiological changes, altering their capacity to produce photosynthetic pigments and, consequently, resulting in harmful effects in the cultures' growth and development (Silva et al., 2017).

Arid and semiarid regions present high salt concentration in their waters, which compromises the establishment of agricultural productions. To deal with the water deficiency and use restriction of the Brazilian Northeastern region, 
we need to adopt a procedure that would enable us the use water of high salinity levels to satisfy the requirements of the agricultural sector (Nascimento et al., 2017).

In this context, the purpose hereof was to evaluate the influence of different substrates and electrical conductivities of the irrigation water on the growth of Malpighia emaginata D.C.

\section{Material and Methods}

The research was performed in the safe environment of the Agri-food Science and Technology Center (CCTA), of the Federal University of Campina Grande (UFCG), Pombal Campus, PB.

The experimental design employed was of randomized blocks, whose treatments were distributed in a $5 \times 4$ factorial scheme, representing five irrigation water salt levels $\left(0.3,1.0,1.7,2.7\right.$, and $\left.3.5 \mathrm{dS} \mathrm{m}^{-1}\right)$ and four substrates $(\mathrm{S} 1=$ soil; $\mathrm{S} 2=$ soil with a $10 \%$ addition of cattle manure; $\mathrm{S} 3=$ soil with a $10 \%$ addition of organic compounds; and S4 - soil with a 5\% addition of cattle manure and a 5\% addition of organic compounds), with four repetitions and two plants by patch.

Waters of different salt levels were obtained from the water supply (CEa of $0.3 \mathrm{dS} \mathrm{m}^{-1}$ ) through the addition of different concentrations of the salts $\mathrm{NaCl}, \mathrm{CaCl}_{2} \cdot 2 \mathrm{H}_{2} \mathrm{O}$, and $\mathrm{MgCl}_{2} \cdot 6 \mathrm{H}_{2} \mathrm{O}$, in the equivalent proportion of $7: 2: 1$, a predominant ratio in the main water sources available for irrigation in the Brazilian Northeast (Medeiros, 1992).

The substrates were obtained through the mixture of fluvic Neosol with the respective proportions of organic matter (cattle manure and/or organic compound), resulting in a homogeneous material. The manure used in the experiment was duly composted, as the organic compound used was made by the addition of cattle manure with rests of the native vegetation and grass straw, as described by Coelho (2008).

The physical and chemical features of the soil used in the research (Table 1) were obtained following Claessen's (1997) methods and analyzed in the Soil and Plant Nutrition Laboratory at the CCTA/UFCG.

Table 1. Physical and chemical features of the soil used in the experiment

\begin{tabular}{|c|c|c|c|c|c|c|c|c|c|c|c|}
\hline \multirow{2}{*}{\multicolumn{2}{|c|}{ Textural classification }} & \multirow{2}{*}{\multicolumn{2}{|c|}{ Apparent density }} & \multirow{2}{*}{\multicolumn{2}{|c|}{ Total porosity }} & \multirow{2}{*}{ Organic matter } & \multirow{2}{*}{$\mathrm{P}$} & \multicolumn{4}{|c|}{ Random complex } \\
\hline & & & & & & & & $\mathrm{Ca}^{2+}$ & $\mathrm{Mg}^{2+}$ & $\mathrm{Na}^{+}$ & $\mathrm{K}^{+}$ \\
\hline \multirow{2}{*}{\multicolumn{2}{|c|}{ Sandy loam }} & \multirow{2}{*}{\multicolumn{2}{|c|}{$\begin{array}{l}\text {------ } \mathrm{g} \mathrm{cm}^{-3} \text {------ } \\
1.38\end{array}$}} & \multirow{2}{*}{\multicolumn{2}{|c|}{$\begin{array}{l}\text {------ \% ------ } \\
47.00\end{array}$}} & ---- $\mathrm{g} \mathrm{kg}^{-1}$----- & $\mathrm{mg} \mathrm{dm}^{-3}$ & \multicolumn{4}{|c|}{ - } \\
\hline & & & & & & 32 & 17 & 5.4 & 4.1 & 2.21 & 0.28 \\
\hline \multicolumn{12}{|c|}{ Saturation extract } \\
\hline \multirow[t]{2}{*}{ pHse } & $\mathrm{CE}_{\mathrm{se}}$ & $\mathrm{Ca}^{2+}$ & $\mathrm{Mg}^{2+}$ & $\mathrm{K}^{+}$ & $\mathrm{Na}^{+}$ & $\mathrm{Cl}^{-}$ & & & $\mathrm{HCO}_{3}^{-}$ & \multicolumn{2}{|c|}{ Saturation } \\
\hline & $\mathrm{dS} \mathrm{m}^{-1}$ & \multicolumn{8}{|c|}{ - } & \multirow{2}{*}{\multicolumn{2}{|c|}{$\begin{array}{l}----- \text { \% ------ } \\
27.00\end{array}$}} \\
\hline 7.41 & 1.21 & 2.50 & 3.75 & 4.74 & 3.02 & 7.50 & & & 5.63 & & \\
\hline
\end{tabular}

Note. $\mathrm{pHse}=\mathrm{pH}$ of the soil's saturation extract; $\mathrm{ECse}=$ Electrical conductivity of the soil's saturation extract at $25{ }^{\circ} \mathrm{C}$.

After establishing the different substrates, they were stored in $288-\mathrm{cm}^{3}$ tubes, which were open at their bottoms to allow a free drainage and were placed on trays over a metal bench, at a height of $0.8 \mathrm{~m}$ above the soil.

As for our vegetable material, we used our access to the acerola tree 'CMI 102', originated from the Manioc and Pomology Embrapa, Cruz das Almas, BA, where they were equidistantly planted, with five seeds by tube, at a depth of $1.0 \mathrm{~cm}$. After the seedlings presented two pairs of true, totally expended leaves, we performed their thinning, leaving only a seedling by container, the most vigorous one.

During the seedlings' period of germination and emergence, the substrate was kept close to the field capacity with a local supply water of $0.3 \mathrm{dSm}^{-1}$, a condition obtained through the drainage lysimetry process, which daily received the volume of evapotranspired water, which was determined by the difference between the applied volume and the drained volume of the previous irrigation, according to Equation 1 (Bernardo, Soares, \& Mantovani, 2006).

$$
\mathrm{Av}=\mathrm{Wcc}-\mathrm{Pa} / \mathrm{n}
$$

Where,

$\mathrm{Av}=$ applied volume; $\mathrm{Wcc}=$ weight of the container at its maximum water retaining capacity; $\mathrm{n}=$ number of containers. 
The irrigations with salt water begun 30 days after seeding through daily, manual irrigations. Sixty days after the application of the treatments, the following variables were measured:

$>$ Leaf number (LN): obtained through the counting of the number of totally formed leaves;

> Plant height $(\mathrm{PH})$ : measured from the plants' aerial part, considering the part above its base, using a graduated ruler with the results expressed in $\mathrm{cm}$;

> Stem diameter (SD): performed with the assistance of a digital caliper, with its results expressed in $\mathrm{mm}$;

$>$ Root length: after the removal of the plants from the substrate, we washed the roots and measured their length with the assistance of a graduated ruler, whose results were expressed in $\mathrm{cm}$;

$>$ Root and aerial part fresh mass: obtained by the weight in an analytical scale of precision, separating the parts at the plants' base height, with results expressed in g plant $^{-1}$;

$>$ Total fresh mass: measured by the sum of the root and aerial part fresh mass. The results were expressed in $\mathrm{g}$ plant $^{-1}$;

$>$ Root and aerial part dry mass: after the separation of the parts, they were stored in paper bags of the Kraft type and deposited into a forced air circulation muffle for drying at $65^{\circ} \mathrm{C}$ until they reached a constant weight. Then we weight the material on a precision analytical scale, whose results were expressed in $\mathrm{g} \mathrm{plant}^{-1}$;

$>$ Total dry mass: obtained by the sum of the values of the root and aerial part dry mass. The results were expressed in g plant $^{-1}$;

> Plant height/stem diameter ratio: obtained by the plant height by stem diameter division results.

$>$ Aerial part/root dry mass ratio: calculated by the division of the values obtained for aerial part and root total dry mass, according to the methods of Fernandes, T. J. D. Rodrigues, Medeiros, and L. R. D. A. Rodrigues (2005). The results were expressed in $\mathrm{g} \mathrm{g}^{-1}$.

> Dickson quality index: determined by plant height (PH), base diameter (BD), aerial part and root dry mass, according to Equation 2 (Dickson, Leaf, \& Hosner, 1960).

$$
\mathrm{DQI}=\mathrm{TDM} /(\mathrm{PH} / \mathrm{BD}) /(\mathrm{APDM} / \mathrm{RDM})
$$

The data were submitted to an analysis of variance and significant cases were submitted to a Polynomial Regression analysis. To perform the analyses, we employed the System for Variance Analysis-SISVAR ${ }^{\circledR}$ software, version 5.6 (Ferreira, 2011).

\section{Results and Discussion}

The values obtained for height and stem diameter of the acerola plants were not affected by the applied treatments. The leaf number was affected by the substrates, where the one composed of soil with a $10 \%$ addition of cattle manure promoted a greater leaf number increase of the acerola tree. The substrate composed of soil with a $10 \%$ addition of organic compound promoted an increase similar to substrate 2's. However, it was not statistically different from all other substrates (Table 2).

Table 2. Number of leaves of Malpighia emaginata D.C. as a function of different substrates, submitted to the Tukey test at $5 \%$ probability

\begin{tabular}{ll}
\hline \multirow{2}{*}{ Substrates } & Variable analyzed \\
\cline { 2 - 2 } & Number of leaves \\
\hline S1 & $12 \mathrm{~b}$ \\
S2 & $15 \mathrm{a}$ \\
S3 & $14 \mathrm{ab}$ \\
S4 & $12 \mathrm{~b}$ \\
\hdashline Avarage & 13 \\
\hline
\end{tabular}

Note. Averages followed by the same letter do not differ from each other by the Tukey test at $5 \%$ probability.

This effect might have been promoted due to the greatest availability of nutrients, resulting in better conditions for the plants' development. The use of cattle manure promotes improvements in the substrate's physical, chemical, and biological features, which happens due to the possibility of generating a better aeration and nutritional balance, 
resulting in a better nutrient absorption of the plants and, consequently, in better conditions for their growth and development (Souza et al., 2017a).

As for root length, we noticed that the values obtained for the substrates composed only by soil with a $10 \%$ addition of organic compounds were adjusted to the quadratic effect, with the greater values of 20.9 and $20.6 \mathrm{~cm}$ at the salt levels of 2.4 and $3.5 \mathrm{dS} \mathrm{m}^{-1}$. As for the substrate composed of soil with a $10 \%$ addition of composted cattle manure, it was adjusted to the ascending linear effect with $20.9 \mathrm{~cm}$ at the greatest salt level. The substrate composed of soil with a $5 \%$ addition of cattle manure and a $5 \%$ addition of organic compounds was adjusted to the descending linear $22.5 \mathrm{~cm}$ with $0.3 \mathrm{dS} \mathrm{m}^{-1}$, occurring a reduction with the irrigation water salinity increase (Figure $1)$.

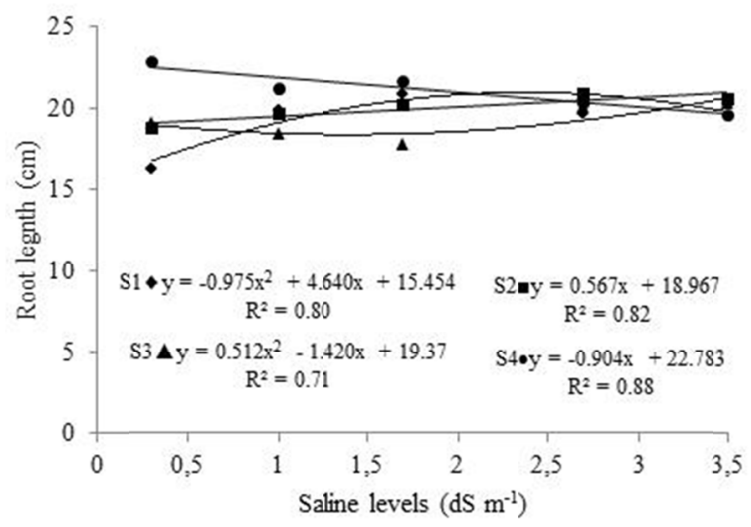

Figure 1. Root length of Malpighia emaginata D.C. as a function of different substrates and saline levels

This root length increase caused by the different substrates is related to the improvements that the used materials provided to the structure, favoring a greater root development. The elements of a substrate must maintain proper conditions to enable their interaction with the plants, which is performed by the roots, and their effectiveness is conditioned to the proper development of the root system and a uniform rooting (Meneghelli et al., 2017).

As for the aerial part fresh mass, the mean values of the different substrates were adjusted to a quadratic effect caused by the salt levels. We can notice that the substrate composed of soil with a $10 \%$ addition of composted cattle manure presented a better behavior in comparison with all the others, with an increase of $1.98 \mathrm{~g} \mathrm{plant}^{-1}$ when submitted to the level of $1.5 \mathrm{dS} \mathrm{m}^{-1}$, a value that is reduced at this salt concentration upwards (Figure 2A). As for the soil, it presented an opposite behavior, with an increase of $1.34 \mathrm{~g} \mathrm{plant}^{-1}$ at the level of $3.5 \mathrm{dS} \mathrm{m}^{-1}$.
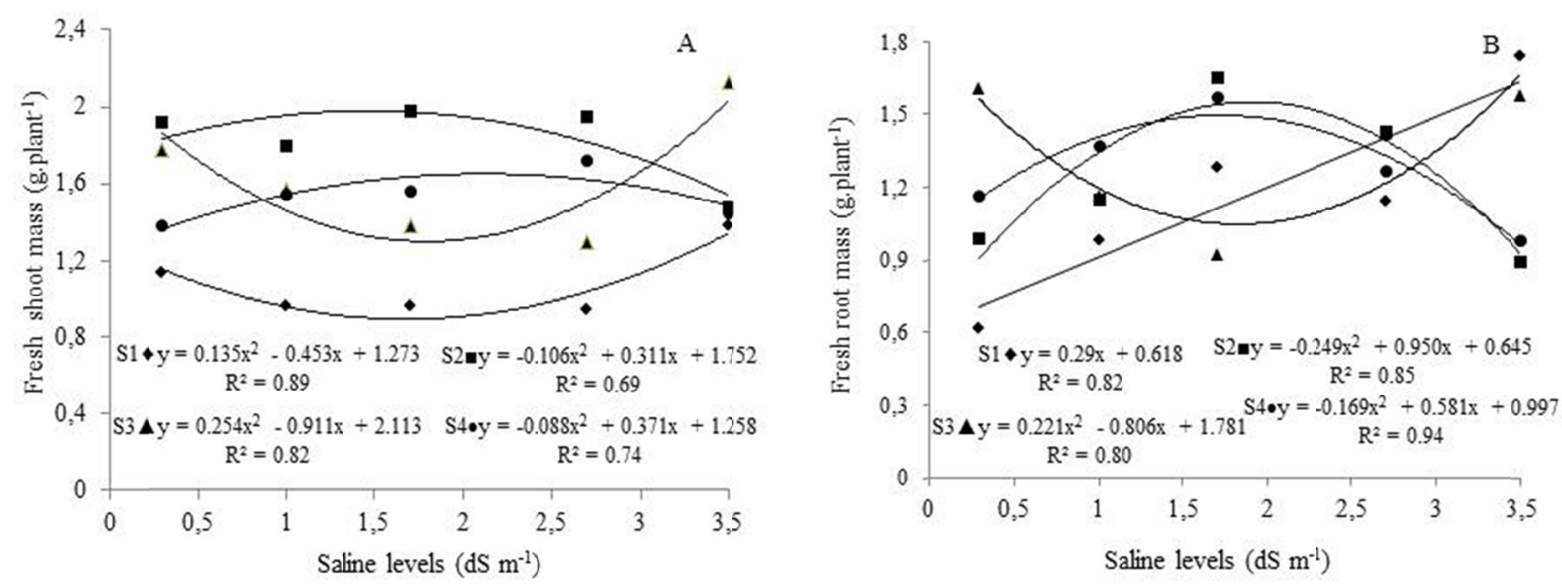


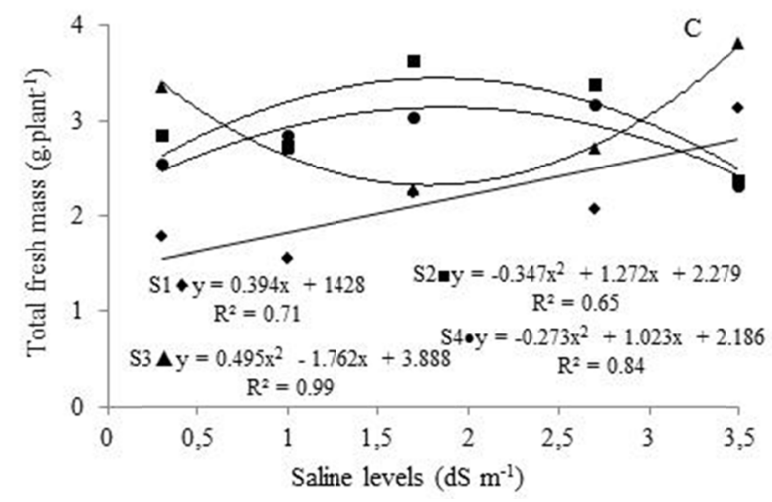

Figure 2. Fresh shoot mass (A), fresh root mass (B) and total fresh mass (C) of Malpighia emaginata D.C. as a function of different substrates and saline levels

This behavior may be related to the presence of composted manure, that is, in an advance process of mineralization, when it can provide the essential nutrients for vegetable development, including nitrogen, phosphorus, and potassium (J. M. R. Reis, Rodrigues \& M. Reis, 2014). Among the parameters affected by the increase of salt concentration, the leaf area is one of the main features, as stated by Cavalcante, Vieira, Santos, Oliveira, and Nascimento (2010), directly affecting the amount of phytomass, which justifies the decrease of the values found herein.

Based on the data obtained for root fresh mass, the substrate composed of soil presented an ascending linear adjustment with the increase of salt concentration, with a maximum increase of $1.74 \mathrm{~g} \mathrm{plant}^{-1}$. All others were adjusted to a quadratic effect (Figure 2B). We noticed that the substrates composed of soil with a $10 \%$ addition of composted cattle manure, and soil with a $5 \%$ addition of cattle manure and a $5 \%$ of organic compounds presented ascending values up to the salt level of $1.5 \mathrm{dS} \mathrm{m}^{-1}$, reaching 1.54 and $1.49 \mathrm{~g} \mathrm{plant}^{-1}$, respectively, descending in greater levels, an opposite behavior to what is noticed in the soil with a $10 \%$ addition of organic compounds.

We can state, based on the results, that the substrates that included manure in their composition favored a greater root development up to the salt concentration of $1.5 \mathrm{dS} \mathrm{m}^{-1}$. It might have happened because manure favors a greater porosity, better water retention, and has several nutrients, which will be made available to the plants, enabling a better development thereof (Bardiviesso, Maruyama, Reis, Modesto, \& Rezende, 2011).

The values for total fresh mass were similar to the ones of root fresh mass, presenting an ascending linear adjustment for the soil with a maximum weight of $2.80 \mathrm{~g} \mathrm{plant}^{-1}$ and quadratic adjustment for all others (Figure 2C). The substrates with manure (S2 and S4) presented increases of 3.44 and $3.14 \mathrm{~g} \mathrm{plant}^{-1}$, respectively, values that began to decrease after the level of $1.5 \mathrm{dS} \mathrm{m}^{-1}$.

This behavior may be explained by the fact that the level of organic matter present in the substrates with cattle manure stimulates the release of humic substances in the soil, which results in greater growth of the roots and aerial part of the plants (Nascimento et al., 2011).

As for the aerial part dry mass, we may notice that the values obtained for the substrates were quadratically adjusted depending on which salt water was used (Figure 3A). The soil with a $10 \%$ addition of organic compound promoted the greater increase in the biomass build-up with $0.64 \mathrm{~g}_{\text {plant }}{ }^{-1}$ in the salinity of $0.3 \mathrm{dS} \mathrm{m}^{-1}$. The substrates composed of soil (S1) and soil with a 5\% addition of cattle manure and a 5\% addition of organic compounds (S4) promoted the maximum increase of $0.45 \mathrm{~g} \mathrm{plant}^{-1}$ in the salinities of 3.5 and $1.3 \mathrm{dS} \mathrm{m}^{-1}$. As for the soil substrate with a $10 \%$ addition of composted cattle manure, it promoted an increase of $0.59 \mathrm{~g} \mathrm{plant}^{-1}$ when submitted to the salt level of $0.8 \mathrm{dS} \mathrm{m}^{-1}$. 

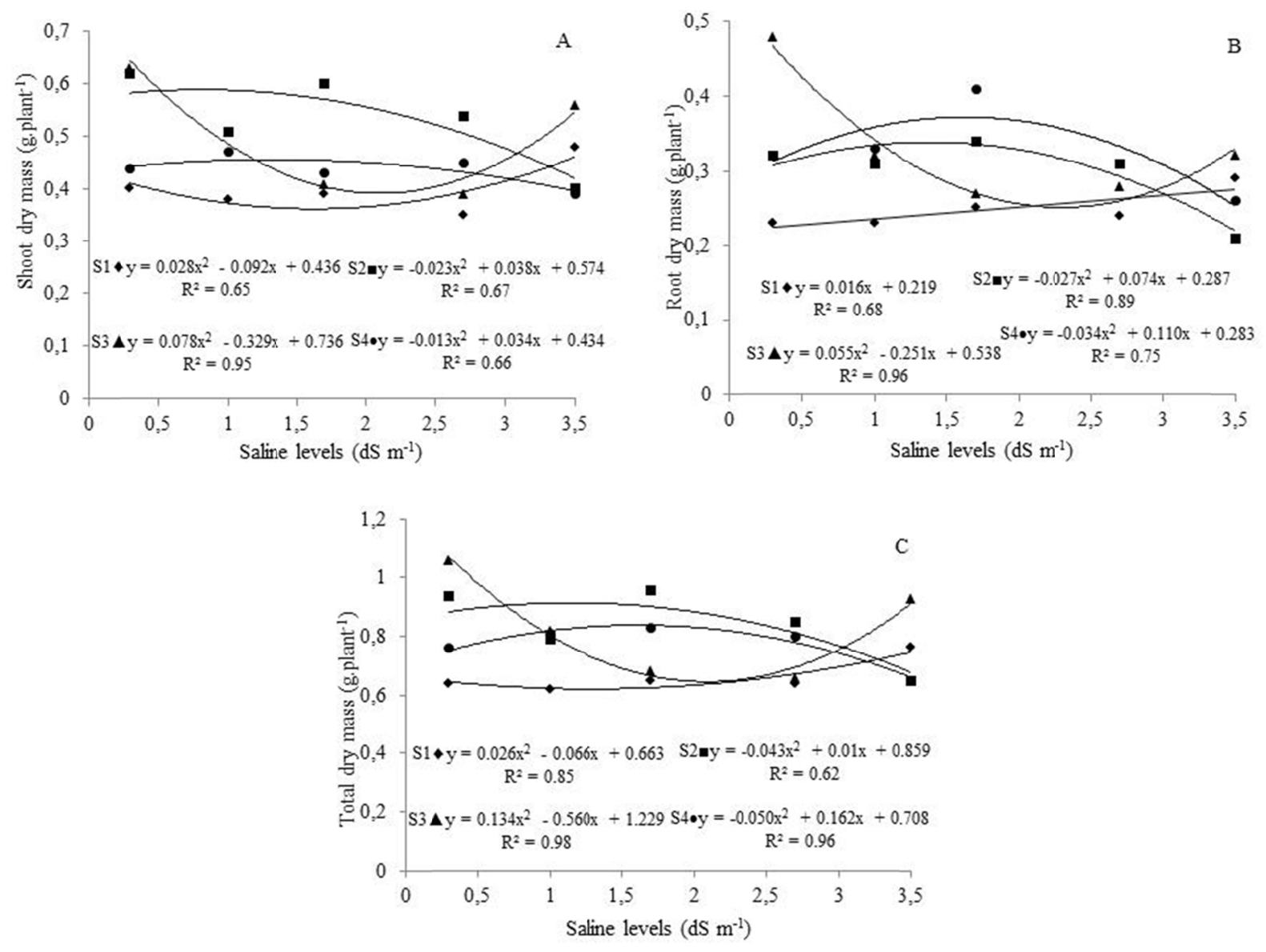

Figure 3. Dry shoot mass (A), root dry mass (B) and total dry mass (C) of Malpighia emaginata D.C. as a function of different substrates and saline levels

This effect proves that even promoting a greater increase in the build-up of biomass, the plants produced in the substrates with the addition of cattle manure and organic compounds suffered several decreases with the increase of salinity, an effect that may be triggered by water deficiency caused by the reduction of the osmotic potential. A water deficiency condition in the substrate reduced the plants' ability to produce phytomass (Lima et al., 2017). One of the main effects of salinity is the reduction of the water absorption ability, which directly affects the aerial part's biomass build-up (F. D. A. Oliveira, M. K. T. Oliveira, Lima, Cássia Alves, Lima Régis \& Santos, 2017b).

As for the root dry mass, the values of the substrates composed of soil with a $10 \%$ addition of composted cattle manure, soil with a $10 \%$ addition of organic compounds, and soil with a $5 \%$ addition of cattle manure and a $5 \%$ addition of organic compounds are adjusted to the quadratic effect, with the maximum values of $0.34,0.47$, and $0.37 \mathrm{~g} \mathrm{plant}^{-1}$ at the salt levels of $1.4,0.3$, and $1.7 \mathrm{dS} \mathrm{m}^{-1}$, respectively. As for the values obtained for the root biomass of the plants produced in the soil, they were adjusted to the ascending linear effect according to the salt levels, with a maximum build-up of $0.27 \mathrm{~g} \mathrm{plant}^{-1}$ (Figure 3B).

This effect might have been caused by the greatest availability of nutrients in the substrates with the presence of manure and organic compounds, enabling a greater build-up of biomass. The presence of organic matter in the substrate causes a greater transport of nutrients for the plants, helps with the water retention and infiltration, and favors their root development (Sales et al., 2017). It also improves the aggregation and flocculation process, promoting a greater efficiency in the drainage and leaching of the high level of salts (Sá et al., 2015).

The total dry mass presented a behavior that was similar to the root biomass', representing the greatest increases noticed in the plants that were produced with the substrates composed of soil with a $10 \%$ addition of composted cattle manure, soil with a $10 \%$ addition of organic compounds, and soil with a $5 \%$ addition of cattle manure and a $5 \%$ addition of organic compounds, occurring a maximum increase of $0.91,1.07$, and $0.84 \mathrm{~g} \mathrm{plant}^{-1}$, in the 
electrical conductivities of 1.2, 0.3 , and $1.6 \mathrm{dS} \mathrm{m}^{-1}$ (Figure 3C). As for the plants produced only with soil, their greatest biomass build-up was at the salinity of $3.5 \mathrm{dS} \mathrm{m}^{-1}$ with $0.75 \mathrm{~g} \mathrm{plant}^{-1}$.

The build-up caused by the substrates containing organic matter stress the importance of improving the soil's features, resulting in better performance for biomass build-up, regardless of in which salinity these build-ups occurred. The excess of salts compromise the plants' physiological and metabolic process. However, the addition of organic compounds decrease the intensity of the salts' effects (Souto et al., 2015). Therefore, the substrates composed of manure and organic compounds resulted in better conditions for the plants' growth.

The ratio obtained between plant height/stem diameter proved that the plants produced in the substrates composed of soil with a $10 \%$ addition of cattle manure and of soil with a $10 \%$ addition of organic compounds presented the greatest values for the ratio with 5.25 and 5.0 at the salinities of 0.3 and $3.5 \mathrm{dS} \mathrm{m}^{-1}$ (Figure 4A). As for the ratio obtained for the plants produced with soil and soil with a $5 \%$ addition of cattle manure and a $5 \%$ addition of organic compounds presented a quadratic effect with the greatest rates at the salinities of 1.8 and $0.3 \mathrm{dS} \mathrm{m}^{-1}$.
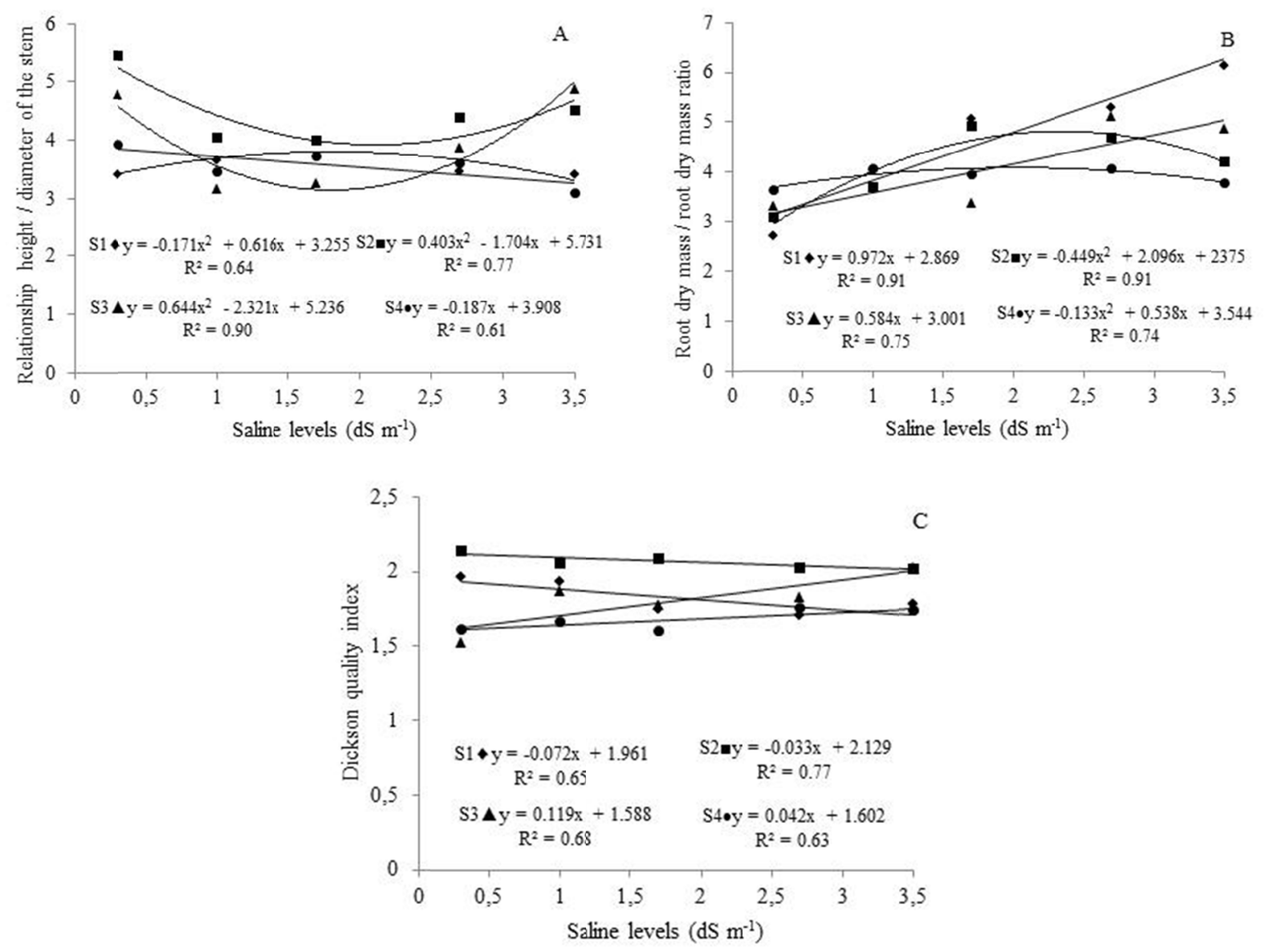

Figure 4. Relationship height/diameter of the stem (A), root dry mass/root dry mass ratio (B) and Dickson quality index (C) of Malpighia emaginata D.C. as a function of different substrates and saline levels

This decrease in the substrates composed of cattle manure is probably caused by the toxic effects of salinity, represented in the plants' growth reduction. The addition of organic matter improves the soil's physical and biological features, as well its fertility, but it also may increase the already existent salinity (Souza et al., 2017b).

As for the ratio between aerial part and root dry mass, we notice that the substrates composed of soil and soil with a $10 \%$ addition of organic compounds presented an ascending linear effect, with increases of 6.27 and 5.04. As for the soil with a $10 \%$ addition of composted cattle manure and soil with a $5 \%$ addition of cattle manure and a $5 \%$ addition of organic compounds, they were adjusted to the quadratic model with greater increases at the salinities of 2.3 and $2.0 \mathrm{dS} \mathrm{m}^{-1}$, respectively (Figure 4B). 
This effect proves that the ratio presented a greatest investment in the growth of the plants' aerial part. This ratio may occur due to a reaction of the plants to luminous stimuli, promoting a greatest growth of the aerial part (Oliveira et al., 2013).

The Dickson quality index (DQI) presented a descending linear effect for the plants produced in the soil and in the substrate soil with a $10 \%$ composted cattle manure, while the seedlings of the substrates composed of soil with a $10 \%$ addition of organic compounds and soil with a $5 \%$ addition of cattle manure and a $5 \%$ addition of organic compounds presented an ascending linear effect according to the increase of salinity (Figure 4C).

The results imply that the salinity was mitigated by the addition of organic matter contained in the substrate, since the substrates that contained cattle manure and organic compounds in their composition promoted a linear increase of the DQI, promoting the generation of more vigorous plants. The inclusion of several variables in the establishment of the DQI indicates a greater balance in the distribution of the plants' biomass, as the ones with greater value represent the plants that are more vigorous (Azevedo, Alencar, Barbosa, \& Almeida, 2010).

\section{Conclusions}

(1) The plant height and stem diameters of Malpighia emaginata D.C. were not affected by the substrates and by the irrigation water's salinity.

(2) The build-up of fresh and dry biomass of $M$. emaginata plants were affected by salinity and by the substrates, presenting the greatest increases in the substrates that received the addition of organic matter.

(3) The height/diameter and aerial part/root dry mass ratios and the Dickson quality index indicate that the substrates composed of soil with a $10 \%$ addition of cattle manure and soil with a $10 \%$ addition of organic compounds produced more vigorous plants.

\section{References}

Barbosa, A. P., de Alencar, R. M., de Almeida, N. O., \& de Azevedo, I. M. G. (2010). Estudo do crescimento e qualidade de mudas de marupá (Simarouba amara Aubl) em viveiro. Acta Amazonica, 40, 157-164. https://doi.org/10.1590/S0044-59672010000100020

Bardiviesso, D. M., Maruyama, W. I., Reis, L. L., Modesto, J. H., \& Rezende, W. E. (2011). Diferentes substratos e recipientes na produção de mudas de guabiroba (Campomanesia pubescens O. Berg). Revista Científica Eletrônica de Agronomia, 18(1), 52-59. Retrieved from http://www.faef.revista.inf.br/imagens_arquivos/ arquivos_destaque/h1kpQ5xFL2BZdeC_2013-5-17-11-38-40.pdf

Bernardo, S., Soares, A. A., \& Mantovani, E. C. (2006). Manual de irrigação (8th ed.) Editora UFV, Viçosa-MG.

Cavalcante, L. F., Vieira, M. S., Santos, A. F., Oliveira, W. M., \& Nascimento, J. A. M. (2010). Água salina e esterco bovino líquido na formação de mudas de goiabeira cultivar Paluma. Revista Brasileira de Fruticultura, 32(1), 251-261. https://doi.org/10.1590/S0100-29452010005000037

Claessen, M. E. (1997). Manual de métodos de análise de solo. Embrapa Solos-Documentos (INFOTECA-E).

Coelho, F. C. (2008). Composto orgânico. Manual Técnico 03, Niterói: Programa Rio Rural, 2008. Retrieved from http://www.pesagro.rj.gov.br/downloads/riorural/03\%20Composto\%20Organico.pdf

Dickson, A., Leaf, A. L., \& Hosner, J. F. (1960). Avaliação da qualidade de mudas de pinheiros brancos e pinheiros brancos em viveiros. The Forestry Chronicle, 36(1), 10-13. https://doi.org/10.5558/tfc36010-1

Esashika, T., Oliveira, L. A., \& Moreira, F. W. (2013). Resposta da aceroleira a adubação orgânica, química e foliar num Latossolo da Amazônia Central. Revista de Ciências Agrárias, 36, 399-410. Retrieved from http://www.scielo.mec.pt/pdf/rca/v36n4/v36n4a03.pdf

Fernandes, A. C., Rodrigues, T. de J. D., Malheiros, E. B., \& Rodrigues, L. R. D. A. (2005). Crescimento inicial da parte aérea e do sistema radicular de três cultivares de alfafa. Revista Brasileira de Engenharia Agrícola e Ambiental, 9(1), 51-56. https://doi.org/10.1590/S1415-43662005000100008

Ferreira, D. F. (2011). Sisvar: Um sistema de análise estatística computacional. Ciência e Agrotecnologia, 35(6), 1039-1042. https://doi.org/10.1590/S1413-70542011000600001

Lima, A. S., Alves, J. M., Silva, F. L., Santos, J. M., Mesquita, E. F., \& Guerra, H. O. C. (2017). substratos e níveis de reposição de água na produção de mudas de melância. Revista Brasileira de Agricultura Irrigada, 11(7), 2010. http://doi.org/10.7127/rbai.v11n700670

Medeiros, J. D. (1992). Qualidade da água de irrigação e evolução da salinidade nas propriedades assistidas pelo "GAT" nos Estados do RN, PB e CE (p. 173). Campina Grande: UFPB. 
Medeiros, S. A. S., Cavalcante, L. F., Bezerra, M. A. F., do Nascimento, J. A. M., Bezerra, F. T. C., \& Prazeres, S. S. (2016). Água salina e biofertilizante de esterco bovino na formação e qualidade de mudas de maracujazeiro amarelo. Irriga, 21(4), 779-795. https://doi.org/10.15809/irriga.2016v21n4p779-795

Meneghelli, L. A. M., Monaco, P. A. V. L., Haddade, I. R., Meneghelli, C. M., Krause, M. R., \& Vieira, G. H. S. (2017). Produção de mudas de café arábica em substrato composto por resíduo da secagem dos grãos. Coffe Science, 12, 381-388. https://doi.org/10.25186/cs.v12i3.1312

Nascimento, E. S., Cavalcante, L. F., Gondim, S. C., Souza, J. T. A., Bezerra, F. T. C., \& Bezerra, M. A. F. (2017). Formação de mudas de maracujazeiro amarelo irrigadas com águas salinas e biofertilizantes de esterco bovino. Agropecuária Técnica, 38(1), 1-8. https://doi.org/10.25066/agrotec.v38i1.28090

Nascimento, J. A., Cavalcante, L. F., Santos, P. D. D., Silva, S. A. D., Vieira, M. D. S., \& Oliveira, A. P. D. (2011). Efeito da utilização de biofertilizante bovino na produção de mudas de pimentão irrigadas com água salina. Revista Brasileira de Ciências Agrárias, 6(2), 258-264. http://doi.org/10.5039/agraria.v6i2a1069

Oliveira, F. D. A., de Oliveira, J. M., de Souza Neta, M. L., de Oliveira, M. K. T., \& de Cássia Alves, R. (2017a). Substratos e bioestimulante na produção de mudas de maxixeiro. Horticultura Brasileira, 35(1), 141-146. https://doi.org/10.1590/s0102-053620170122

Oliveira, F. D. A., de Oliveira, M. K. T., Lima, L. A., de Cássia Alves, R., de Lima Régis, L. R., \& dos Santos, S. T. (2017b). Estresse salino e biorregulador vegetal em feijão caupi. Irriga, 22(2), 314-329. Retrieved from http://revistas.fca.unesp.br/index.php/irriga/article/view/2180/1726

Oliveira, F. T., Hafle, O. M., Mendonça, V., Moreira, J. N., \& Júnior, E. B. P. (2013). Fontes orgânicas e volumes de recipiente no crescimento inicial de porta-enxertos de goiabeira. Revista Verde de Agroecologia e Desenvolvimento Sustentável, 8(2), 97-103. Retrieved from http://www.gvaa.com.br/revista/index.php/ RVADS/article/view/2164/1686

Prates, F. B. S., Lucas, C. S. G., Sampaio, R. A., Brandão Júnior, D. S., Fernandes, L. A., \& Zuba Junio, G. R. (2012). Crescimento de mudas de pinhão-manso em resposta a adubação com superfosfato simples e pó-de-rocha. Revista Ciência Agronômica, 43(2), 207-213. https://doi.org/10.1590/S1806-669020120002 00001

Reis, J. M. R., Rodrigues, J. F., \& Reis, M. (2014). Produção de mudas de maracujazeiro amarelo com diferentes substratos. Enciclopédia Biosfera, 10(18), 2422-2428. Retrieved from http://www.conhecer.org.br/enciclop/ 2014a/AGRARIAS/producao\%20de\%20mudas.pdf

Sá, F. V. S., Brito, M. E. B., Pereira, I. B., Neto, P. A., de Andrade Silva, L., \& da Costa, F. B. (2015). Balanço de sais e crescimento inicial de mudas de pinheira (Annona squamosa L.) sob substratos irrigados com água salina. Irriga, 20(3), 544. https://doi.org/10.15809/irriga.2015v20n3p544

Sales, R. A., de Sales, R. A., do Nascimento, T. A., da Silva, T. A., da Silva Berilli, S., \& dos Santos, R. A. (2017). Influência de diferentes fontes de matéria orgânica na propagação da Schinus terebinthifolius Raddi. Scientia Agraria, 18(4), 99-106. https://doi.org/10.5380/rsa.v18i4.54203

Santos, B. A., Leite, J. L. N., da Silva, K. R., de Oliveira, I. V., \& de Mello, A. H. (2017). Produção de mudas de acerola (Malpighia emarginata DC) pelo método de enxertia em topo por garfagem em fenda cheia. Revista Agroecossistemas, 9(1), 251-260. https://doi.org/10.18542/ragros.v9i1.4775

Silva, E. M., Nobre, R. G., Souza, L.P., Pinheiro, F. W. A., de Lima, G. S., Gheyi, H. R., \& de Sá Almeida, L. L. (2017). Fisiologia de goiabeira 'Paluma'sob irrigação com água salina e adubação nitrogenada. Semina: Ciências Agrárias, 38(2), 623-634. https://doi.org/10.5433/1679-0359.2017v38n2p623

Souto, A. G. L., Cavalcante, L. F., Diniz, B. L. M. T., Mesquita, F. O., Nascimento, J. A. M., \& Lima Neto, A. J. (2015). Água salina e biofertilizante bovino na produção de frutos e alocação de biomassa em noni (Morinda citrifolia L.). Revista Brasileira de Plantas Medicinais, 17(2), 340-349. https://doi.org/10.1590/ 1983-084X/13_039

Souza, F. M., Lima, E. C. S., da Silva Sá, F. V., Souto, L. S., Araújo, J. E. S., \& de Paiva, E. P. (2017a). Emergência e crescimento inicial de plantas de milho sob déficit hídrico e doses de esterco bovino. Revista Verde de Agroecologia e Desenvolvimento Sustentável, 12(3), 524-529. https://doi.org/10.18378/rvads. v12i3.4896 
Souza, M. C. M. R., Menezes, A. S., da Costa, R. S., Amorim, A. V., \& de Lacerda, C. F. (2017b). Tolerância à salinidade e qualidade de mudas de noni sob diferentes ambientes e matéria orgânica. Revista Brasileira de Agricultura Irrigada, 11(7), 2052-2062. http://doi.org/10.7127/rbai.v11n700682

\section{Copyrights}

Copyright for this article is retained by the author (s), with first publication rights granted to the journal.

This is an open-access article distributed under the terms and conditions of the Creative Commons Attribution license (http://creativecommons.org/licenses/by/4.0/). 